\title{
Expression of the atrial natriuretic peptide gene in the cardiac muscle of rat extrapulmonary and intrapulmonary veins
}

\author{
D R SPRINGALL, M BHATNAGAR, J WHARTON, Q HAMID, S GULBENKIAN, \\ M HEDGES, L MELEAGROS, S R BLOOM, J M POLAK
}
From the Departments of Histochemistry and Medicine, Royal Postgraduate Medical School, Hammersmith Hospital, London

\begin{abstract}
Atrial natriuretic peptide is a peptide regulating salt and water balance, originally isolated from the cardiac atrium, where it is synthesised as part of a precursor molecule in specialisedo myocardial cells. The myocardium extends into the extrapulmonary part of the pulmonary veins in many species, including man. In some small mammals, however, such as the rat, mouse, and bat, it extends further to veins in the peripheral parts of the lung. Since this myocardial layer is continuous $\overrightarrow{0}$ with that in the atrium, we have looked for the possible expression of the atrial natriuretic peptidee gene in this tissue in rats. Strong immunoreactivity was seen for both the peptide and the $N$ terminalo sequence (cardiodilatin) of its precursor in extrapulmonary veins and in intrapulmonary veinss extending into the lung as far as the second branching point, where it was localised in the dense coredo granules by electron microscopy; in situ hybridisation showed atrial natriuretic peptide messengero RNA at identical sites. Chromatography and radioimmunoassay of extracts of extrapulmonary and $Q$ intrapulmonary veins showed most of the atrial natriuretic peptide immunoreactivity to be in the $\overrightarrow{\overrightarrow{0}}$ uncleaved (precursor molecule) form. Thus the peptide is synthesised in veins both outside and inside ${ }^{3}$ the lung, and these extra-atrial sites may be an important additional source of circulating atria年 natriuretic peptide.
\end{abstract}

Atrial natriuretic peptide (atrial natriuretic factor) is a peptide having effects on blood pressure, renal function, and salt balance, ' isolated originally from cardiac atria of several mammalian species. ${ }^{2-5}$ It is stored in cardiac myocytes as a 126 amino acid precursor molecule in dense cored granules, ${ }^{167}$ which are similar to those found in many endocrine cells. ${ }^{8}$ This precursor contains another peptide, cardiodilatin, at its $N$ terminus, from which bioactive 28 amino acid atrial natriuretic peptide (ser ${ }^{99}$ to $\mathrm{tyr}^{126}$ ) is cleaved during or after secretion. Rat and human $\alpha$ atrial natriuretic peptides are very similar, differing by only one amino acid. The interspecies variation in cardiodilatin is greater, with three substitutions within the first $(N$ terminal) 16 amino acids. Immunoreactivity for atrial

Address for reprint requests: Professor J M Polak, Histochemistry Department, Royal Postgraduate Medical School, London W12 0HS.

Accepted 21 September 1987 natriuretic peptide is also found in extra-atrial tissues including ventricle, $^{79}$ pituitary, kidney, adrenaß medulla, ${ }^{10}$ salivary gland, ${ }^{6}$ eye,${ }^{11}$ brain, ${ }^{12}$ and lung. ${ }^{9}$ 130 Synthesis of the peptide, however, as demonstrated by the presence of atrial natriuretic peptide messenger (mRNA) RNA as well as immunostaining, has been found so far to occur only in atrium, ventricle, ${ }^{914}$ lung ${ }^{9}$ and pituitary. ${ }^{9}$

In man the myocardium extends outside the heari no further than the extrapulmonary veins. ${ }^{17}$ In rodents, however, the cardiac muscle is known to extend beyond the atrium along pulmonary veins ando into intrapulmonary veins. ${ }^{18}$ In some species it is seen as far peripherally as the postcapillary venules, the so? called "pulmonary myocardium." 19 Electron micro- 0 scopy has shown these muscle cells to contain dense? cored granules ${ }^{20}$ similar to those in the atrium. We have therefore investigated the possibility that atria $\overrightarrow{\mathbb{B}}$ natriuretic peptide is produced by the myocardium ino these blood vessels. 


\section{Methods}

We used 26 male Wistar rats (mean (SD) weight 250 (5) g), previously allowed food and water ad libitum. Eleven were killed by overdose of sodium pentobarbitone (Euthatal, May and Baker) and the lungs and heart were dissected out intact. Of these, the left lung and ventricles were removed from the tissues of five animals and the right lungs with attached atria were processed for immunocytochemical study; from the other six the tissues were extracted for radioimmunoassay and chromatography. The remaining 15 rats were anaesthetised by intraperitoneal injection of sodium pentobarbitone and perfused transcardially either with Bouin's fluid for immunocytochemical study, with glutaraldehyde for electron microscopy or $4 \%$ paraformaldehyde solution for in situ hybridisation (five in each group).

\section{IMMUNOCYTOCHEMISTRY}

The right lung and atrium were fixed intact in Bouin's fluid for 16 hours, extensively washed in $30 \%$ alcohol, and processed to paraffin wax. Tissue was orientated in the wax blocks so that the atrium and extrapulmonary and intrapulmonary veins could all be seen in the same section. Sections ( $5 \mu \mathrm{m}$ thick) were taken up on poly-L-lysine coated slides. ${ }^{21}$ Immunostaining was performed by the modified immunogold-silver staining (IGSS) technique..$^{22}$ Sections were dewaxed and rehydrated, and then immersed in Lugol's iodine for five minutes, and in $2 \%$ aqueous sodium thiosulphate solution for 30 seconds. After being washed in buffer 1 $(0.05 \mathrm{~mol} / \mathrm{l}$ tris- $\mathrm{HCl}$ buffer $\mathrm{pH} 7.4$, containing $2.5 \%$ $\mathrm{NaCl}$ and $0.5 \%$ Tween 80 ) slides were incubated with undiluted normal goat serum for 30 minutes, followed by appropriately diluted anti-atrial natriuretic peptide (anti-ANP) (dilution 1:4000) or anticardiodilatin (dilution 1:2000) serum for 90 minutes. The antisera were raised in rabbits against synthetic whole human ANP or cardiodilatin ${ }^{1-16}$; both cross react with the respective rat peptides (see also section of radioimmunoassay). After being washed in buffer 1 slides were rinsed in buffer $2(0.5 \mathrm{~mol} / \mathrm{l}$ tris- $\mathrm{HCl}, \mathrm{pH} 8.2)$. Goat anti-rabbit immunoglobulin adsorbed to $5 \mathrm{~nm}$ colloidal gold (GAR G5, Janssen Life Sciences), diluted $1: 200$ in buffer 2 containing $0.8 \%$ bovine serum albumin, was then applied for 60 minutes. Slides were washed in buffer 2 and then in distilled water, and the colloidal gold particles rendered visible for light microscopy by means of a silver intensification reagent (Intense II, Janssen Life Sciences). After counterstaining with haematoxylin or haematoxylin and eosin sections were dehydrated, cleared, and mounted in DPX (RA Lamb).

The controls for immunostaining and silver development were omission of primary antibody or immunogold reagent or both. The specificity of ANP and cardiodilatin antisera was assessed by preabsorption of diluted antiserum with $\mathrm{ANP}^{1-28}$ or cardiodilatin $^{1-16}$ respectively at a concentration of 10 $\mathrm{nmol} / \mathrm{ml}$.

\section{PHOSPHOTUNGSTIC ACID HAEMATOXYLIN}

STAINING

The sections of tissue fixed in Bouin's fluid and embedded in wax to be used for immunocytochemistry were stained by the phosphotungstic acid-haematoxylin method ${ }^{23}$ to show cardiac muscle.

\section{ELECTRON MICROSCOPY}

The respiratory tract and heart were removed intact from rats perfused transcardially with $2 \%$ glutaraldehyde solution in $0.1 \mathrm{~mol} / 1$ phosphate buffer, $\mathrm{pH} 7 \cdot 2$. Veins between the atrium and the hilum of the right lung (extrapulmonary) and the main branch of the vein within the lung (intrapulmonary) were dissected out. The atrial end of the extrapulmonary and the hilar end of the intrapulmonary veins were discarded and the tissues post-fixed in the same glutaraldehyde solution for two hours. After being washed for one hour in $0.1 \mathrm{~mol} / 1$ phosphate buffer $(\mathrm{pH} \mathrm{7.4)}$ containing $0.1 \mathrm{~mol} / 1$ sucrose, tissues were dehydrated in a graded series of ethanols, cleared in propylene oxide, and infiltrated with Araldite epoxy resin. Semithin $(1 \mu \mathrm{m})$ sections from all blocks were taken up on glass slides and immunostained by the peroxidase-antiperoxidase method $^{24}$ with the same anti-ANP (dilution 1:4000) or anti-cardiodilatin (dilution 1:2000) sera that were used for IGSS. Sections were screened to determine the best areas for electron microscopy and the corresponding blocks trimmed to remove unwanted areas. Ultrathin $(70 \mathrm{~nm})$ sections from these blocks were collected on nickel grids, etched for 10 minutes with $10 \%$ aqueous $\mathrm{H}_{2} \mathrm{O}_{2}$, and rinsed in distilled water. Sections were then incubated by floating the grids face down on drops of normal goat serum (diluted 1:30, $30 \mathrm{~min}$ ), followed by incubation with the same anti-ANP or anti-cardiodilatin sera that were used for IGSS (dilution 1:600, $16 \mathrm{~h}$ ) and goat anti-rabbit immunoglobulin antibody adsorbed to $20 \mathrm{~nm}$ gold colloidal particles (GAR G20, Janssen Life Sciences, diluted 1:15, 1 h). After counterstaining in uranyl acetate and lead citrate, preparations were screened and photographed with a Zeiss 10CR electron microscope operating at $60 \mathrm{kv}$. Antiserum specificity was assessed by preabsorption with homologous antigen as for light microscopic immunocytochemistry.

\section{IN SITU HYBRIDISATION}

A plasmid clone containing a cDNA fragment encoding the precursor of rat $\mathrm{ANP}^{25}$ was used as the source of cDNA for the preparation of a complementary 
RNA probe. The SP6 plasmid used for the synthesis of probes complementary to the coding sequence (cRNA probe) of rat ANP mRNA was constructed by inserting the Pst $I$ fragment (620 nucleotides) of cDNA (prANP10) into the polylinker region of pSP64. This recombinant plasmid, pSP-rANP-PP, was linearised with EcoRI ${ }^{26}$ and labelled rat cRNA or mRNA transcripts of ANP-cDNA were synthesised as described previously. ${ }^{14}$ The RNA probe was purified by extraction with phenol and chloroform and precipitated overnight in ethanol at $-20^{\circ} \mathrm{C}$. The total activity was about $1.1 \times 10^{7} \mathrm{cpm}$ for probes labelled with phosphorus-32 and $2.5 \times 10^{7} \mathrm{cpm}$ for probes labelled with sulphur-35.

Anaesthetised rats were perfused transcardially with $200 \mathrm{ml}$ of ice cold PBS followed by $150 \mathrm{ml}$ of $4 \%$ paraformaldehyde solution in $0.1 \mathrm{~mol} / 1$ phosphate buffer (pH 7.4). The lungs and heart were removed intact and post-fixed in the same solution for four hours and then rinsed in PBS containing $15 \%$ sucrose overnight at $4^{\circ} \mathrm{C}$. Cryostat sections $(20 \mu \mathrm{m})$ were mounted on slides coated with poly-L-lysine, dried overnight at $37^{\circ} \mathrm{C}$, and then permeabilised with a $0.3 \%$ solution of Triton X-100 in PBS (15 min) followed by proteinase $\mathrm{K}$ solution ${ }^{27}$ and then $4 \%$ paraformaldehyde in PBS ( $5 \mathrm{~min}$ ), and pre-hybridised in $50 \%$ formamide and $2 \mathrm{X} \mathrm{SSC}$ for 15 minutes at $37^{\circ} \mathrm{C}$. Hybridisation was carried out with 2-3 ng of cRNA probe (about $5 \times 10^{5} \mathrm{cpm} / \mathrm{section} ; 0 \cdot 2-0.3 \mathrm{ng} / \mu \mathrm{g}$ ), as described previously, ${ }^{14}$ for $16-20$ hours at $37^{\circ} \mathrm{C}-42^{\circ} \mathrm{C}$. The preparations were dehydrated through graded alcohols containing $0.3 \mathrm{~mol} / 1$ ammonium acetate, dried, and dipped in Ilford K-5 emulsion and exposed for $2-4$ days at $4^{\circ} \mathrm{C}$ before development in a Kodak D19 developer.

The specificity of in situ hybridisation was tested by hybridising separate sets of sections either with cRNA probe after treatment of sections with RNAase or with non-complementary mRNA probes indentical to the coding strand of the mRNA of rat ANP.

\section{RADIOIMMUNOASSAY AND CHROMATOGRAPHY}

The lung and heart tissues were dissected rapidly. We then took samples of right atrium, extrapulmonary vein, intrapulmonary vein cleaned of adhering lung tissue, and peripheral lung consisting mostly of alveolar tissue. Tissues were extracted, immediately after dissection, by boiling them in $0.5 \mathrm{~mol} / 1$ acetic acid $(10 \% \mathrm{w} / \mathrm{v})$ for 10 minutes and than stored at $-20^{\circ} \mathrm{C}$ until assay or chromatography for $\mathrm{ANP}^{7}$ or cardiodilatin. ${ }^{28}$ Antisera were raised in rabbits immunised with $\alpha$ human ANP (Peninsula Laboratories), or with the asn'-lys ${ }^{16} N$ terminal fragment of the prohormone (Peninsula Laboratories). The ANP antiserum showed $100 \%$ cross reactivity with rat ANP; the cross reactivity of the anti-cardiodilatin serum with the rat peptide is not known, but is presumed to be less than $\Rightarrow$ $100 \%$. The cross reactivity with the whole proANP年 molecule is not known for either antiserum. The? tracers were prepared by iodination of $\alpha$ human ANP $\overline{\overline{\bar{O}}}$ or the asn'-lys ${ }^{16}$ fragment by the chloramine T oxida- $-\frac{\bar{\sigma}}{\sigma}$ tion method with $\mathrm{Na}^{125}$ I (Amersham). The radioim- $-\mathrm{D}$ munoassays were set up in duplicate polystyrene tubes containing $0.06 \mathrm{~mol} / \mathrm{l}$ sodium potassium phosphatebuffer (with $0.3 \% \mathrm{w} / \mathrm{v}$ bovine serum albumin, $0 \cdot 01_{-}^{\circ}$ $\mathrm{mol} / \mathrm{l}$ edetic acid and $0.05 \% \mathrm{w} / \mathrm{v}$ sodium azide). $\operatorname{Ten}_{\bar{\omega}}$ microlitres of diluted $\left(1: 100\right.$ or $1: 1000$ in $0.5 \mathrm{~mol} /{ }^{\circ}$ acetic acid) tissue extracts were added to the sample tubes. Standard curves were constructed with synth $\frac{\vec{\omega}}{\omega}$ etic $\alpha$ human ANP and with the asn ${ }^{1}-$ lys $^{16}$ synthetic fragment. Ten microlitres of $0.5 \mathrm{~mol} / \mathrm{l}$ acetic acid were added to all the standard tubes. After incubation ato $4^{\circ} \mathrm{C}$ for four days the bound and free peptides were separated by adding $4 \mathrm{mg}$ of charcoal and $400 \mu \mathrm{g}$ of dextran per tube. After centrifugation at $800 \mathrm{~g}$ at $4^{\circ} \mathrm{C} \stackrel{\varrho}{:}$ the supernatant (antibody bound peptide) wasy separated from the charcoal pellet (free peptide) and $\mathbb{R}$ both were counted on a gamma counter. The assaye detection limits, with $95 \%$ confidence, are $1 \mathrm{fmol} /$ tubee for ANP and $4 \mathrm{fmol} /$ tube for cardiodilatin immunoreactivity. Assay coefficients of variation for ANP会 were $6 \%$ (intra-assay) and $9 \%$ (inter-assay), and correspondingly for cardiodilatin $9 \%$ and $12 \%$,.

Tissue fractionation was carried out on a $0.9 \mathrm{~cm} \times \stackrel{\circ}{\mathbb{Q}}$ $90 \mathrm{~cm}$ gel column (Pharmacia) containing $60 \mathrm{ml}$ of Sephadex G-100. The column was eluted at a flow rate of $4.8 \mathrm{ml} / \mathrm{h}$ and 20 minute fractions $(1.6 \mathrm{ml} \text { a fraction })^{3}$ were collected. An aliquot of each eluting fraction was assayed for ANP and for cardiodilatin immunoreactivity. Three separate chromatographic runs were undertaken for each tissue type. Alpha rat ANP and cardiodilatin asn'-arg ${ }^{67}$ (synthetic 67 amino acid $N_{O}^{x}$ terminal fragment of the prohormone, Peninsulab. Laboratories) were chromatographed separately and their elution positions were determined.

\section{Results}

The presence of striated cardiac muscle within cardiac. atrium and the wall of intrapulmonary and extrapul o monary veins, but not arteries, was demonstrated by clear blue staining with the phosphotungstic acio haematoxylin method, which is known to stain striated muscle $^{29}$ (fig 1). These areas of cardiac muscle showed strong immunoreactivity by immunogold은 silver staining with specific antisera for ANP and fo cardiodilatin (fig 2). The staining had a strong perinu= clear pattern, characteristic of the pattern seen for ANP in atrial myocytes. ${ }^{7}$ The proportion of myocar dial cells displaying immunoreactivity for either pep $\frac{\text { P }}{\mathbb{D}}$ tide decreased after the vessels entered the lung? Beyond the first intrapulmonary branching point only, 

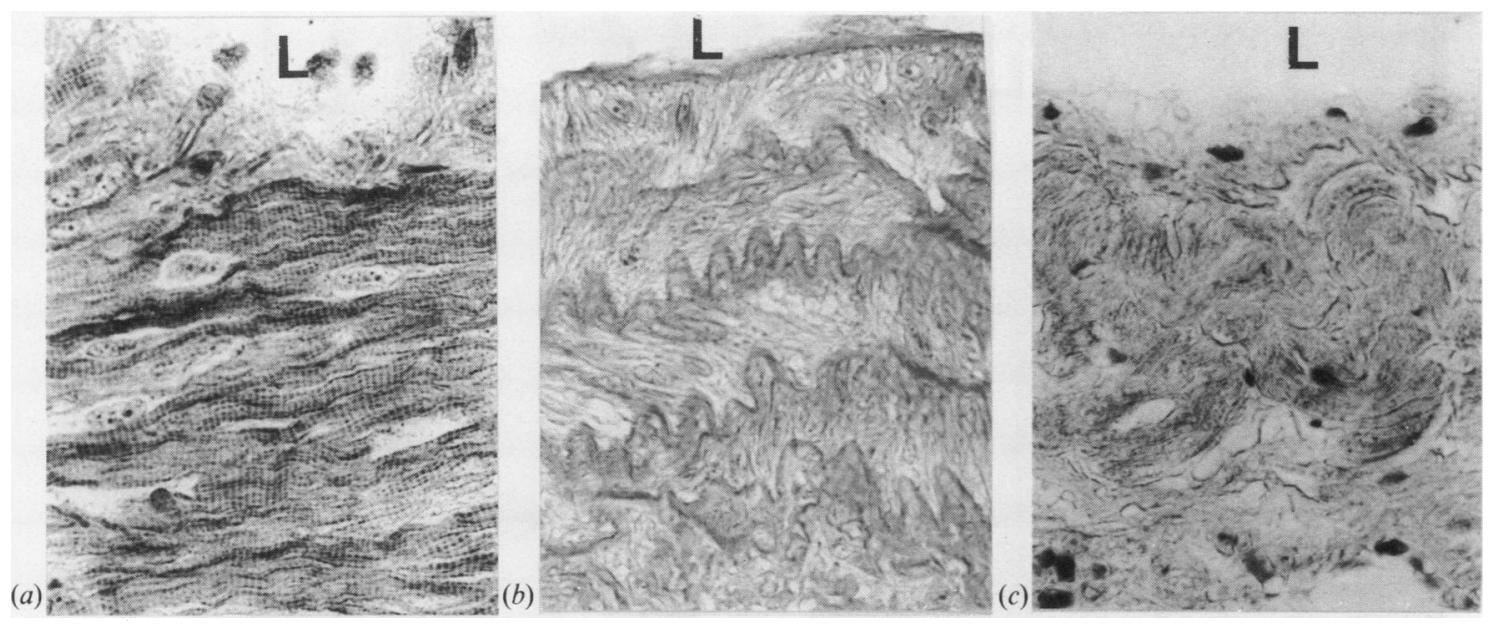

Fig 1 Longitudinal sections of blood vessels stained with phosphotungstic acid-haematoxylin to show that cardiac muscle is present in extrapulmonary veins (a), but not arteries (b). The muscle striations are clearly seen in (a). The same muscle is also seen in intrapulmonary veins (c). L-lumen. ( $5 \mu \mathrm{m}$ wax sections of Bouin's fluid fixed tissue.)

scattered immunoreactive cells were seen, and none was detected beyond the second branching point, although a thin myocardial sheath was often seen. The immunostaining intensity and the frequency of immunoreactive cells was somewhat lower in the perfusion fixed specimens, particularly in the intrapulmonary vessels, where almost no immunoreactive cells were seen. Absorption tests of the antisera used showed that they were specific for their respective antigens.

Electron microscopic immunocytochemical study of ultrathin resin sections showed that immunoreactivity for both ANP and cardiodilatin was localised in dense cored granules (diameter 160-240 nm) in cardiac myocytes in extrapulmonary and intrapulmonary veins (fig 3); the cells on the intimal side of the cardiac muscle sheath appeared to contain more secretory granules than those on the adventitial side. The striated nature of the muscle could be discerned easily by electron microscopy and was also clearly visible in thin resin sections by light microscopy.

Hybridisation of the radiolabelled cRNA probe to the mRNA encoding ANP precursor was revealed by the presence of silver grains in the autoradiograms. These deposits were seen over atrial myocytes and over the cardiac muscle in extrapulmonary and intrapulmonary veins (fig 4). The position of the labelled cells corresponded to that of the cells showing cardiodilatin and ANP immunoreactivities. The strongest hybridisation labelling and greatest density of cells labelled with cRNA was seen in the atrium and extrapulmonary veins. Lower levels of labelling occurred in intrapulmonary veins and was present in scattered cells only. Labelling was not obtained in sections that had been pretreated with RNAase, or if non-complementary RNA probes were used.

The ANP and cardiodilatin concentrations measured by radioimmunoassay in atrial tissues and in extrapulmonary and intrapulmonary venous tissues are shown in the table. The highest concentrations were detected in the atrial tissues with decreasing concentrations in the extrapulmonary and the intrapulmonary veins and no detectable ANP or cardiodilatin immunoreactivity in peripheral lung (principally alveolar) tissue. The immunoreactivities were characterised by gel chromatographic fractionation of the tissue extracts (fig 5). A single peak that was eluted in the same fractions for both ANP and cardiodilatin contained most of the recovered immunoreactivity. A small amount of ANP immunoreactivity was eluted at the position of the synthetic $\alpha$ rat ANP, and some cardiodilatin immunoreactivity was detected between the elution points of the prohormone and the asn- ${ }^{1}-\arg ^{67} N$ terminal fragment.

\section{Discussion}

Our findings demonstrate that myocardium in the extrapulmonary and intrapulmonary veins of the rat contains atrial natriuretic peptide and cardiodilatin immunoreactivity. Most of the myocytes in the extrapulmonary veins contained peptide immunoreactivity, but as the veins extended into the lung the proportion of cells displaying atrial natriuretic peptide and cardiodilatin immunoreactivity declined. This was confirmed by immunocytochemistry, in situ hybridisation, and radioimmunoassay. Ultrastruc- 

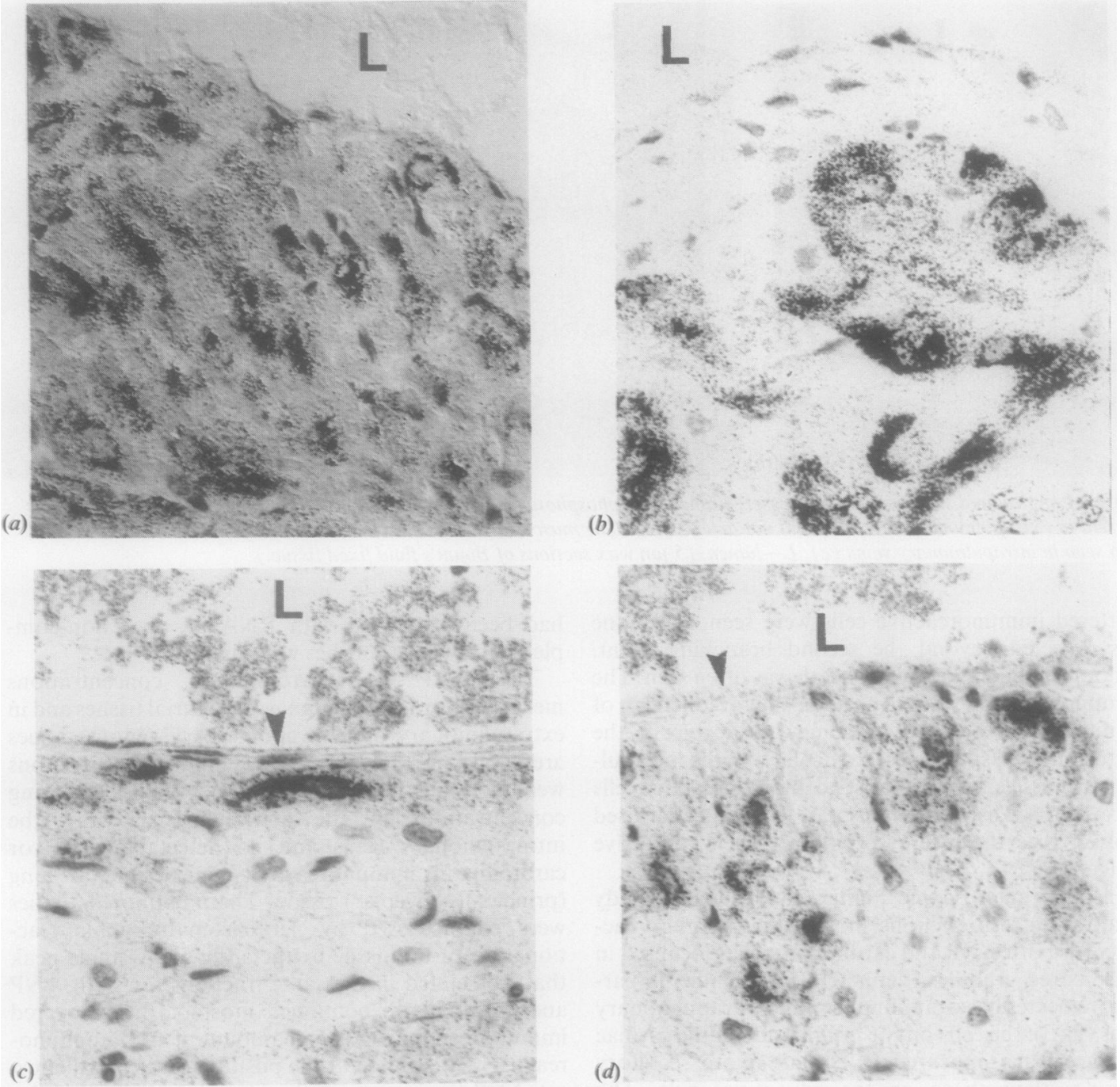

Fig 2 Immunostaining of atrial natriuretic peptide ( $a$ and $c$ ) and cardiodilatin ( $b$ and d) in cardiac muscle sheath of extrapulmonary ( $a$ and $b$ ) and intrapulmonary veins ( $c$ and d). Strong staining with both antisera is seen in myocardial cells, particularly in the extrapulmonary veins. L-humen; arrow heads indicate endothelium. ( $5 \mu m$ wax sections of Bouin's fuid fixed tisswe, immunogold-silver staining.)

turally atrial natriuretic peptide and cardiodilatin immunoreactivities were localised in dense cored secretory vesicles with a diameter of $160-240 \mathrm{~nm}$, features characteristic of the vesicles in atrial myocytes producing atrial natriuretic peptide. ${ }^{700}$ Although this peptide has previously been detected by radioimmunoassay in rat lung extracts ${ }^{13}$ and has been thought to occur in cells of the parenchyma, its presence in intrapulmonary blood vessels is a novel finding.
The strong perinuclear immunoreactivity for atria natriuretic peptide in many of the pulmonary vein myocytes indicates local synthesis rather than uptak of circulating peptide via receptors. This is supported by the presence of ANP mRNA and the finding of immunoreactivity for the $\boldsymbol{N}$ terminal sequence (cart diodilatin) of the atrial natriuretic peptide precursof with an identical distribution pattern. Furthermore the chromatographic analysis of tissue extracts shows 

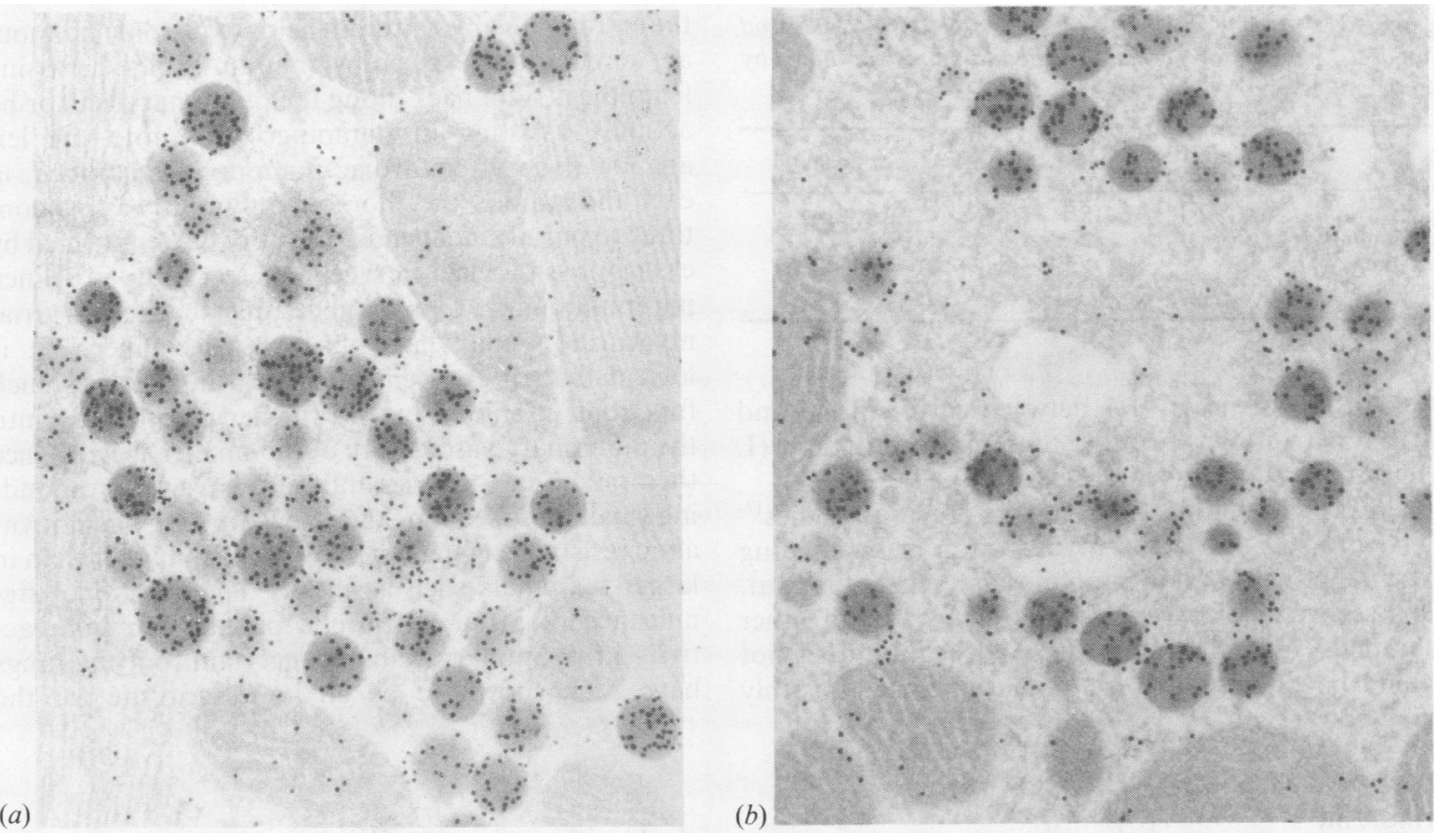

Fig 3 Electron microscopic immunostaining of atrial natriuretic peptide $(a)$ and cardiodilatin $(b)$ in myocardial cells of intrapulmonary veins. Gold colloid particles (20 nm diameter) showing sites of immunoreactivity for both atrial natriuretic peptide and cardiodilatin are located over dense cored granules in the myocardial cells. (Ultrathin resin sections of glutaraldehyde fixed tissue; immunogold staining.)

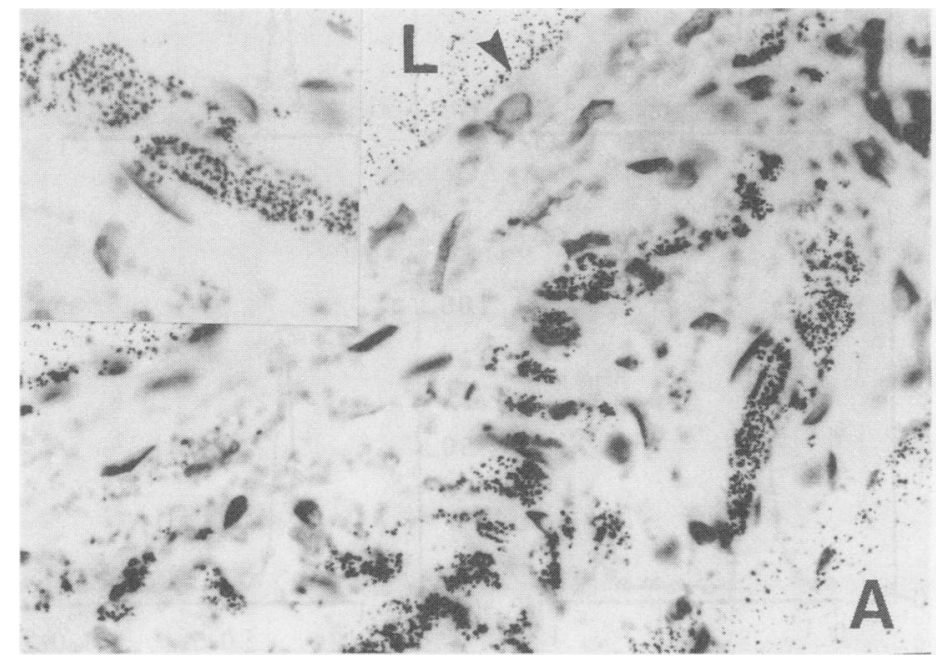

Fig 4 In situ hybridisation of atrial natriuretic peptide $m R N A$ in a pulmonary vein using $a^{32} P$ labelled $c R N A$ probe. Positive labelling is seen over the cytoplasmic area of many myocytes throughout the wall of the vein and shown in higher power in the inset. L-lumen; $A$-adventitia; arrow heads indicate endothelium. (Autoradiogram of cryostat section $(7 \mu \mathrm{m})$ of paraformaldehyde fixed tissue.)

that the immunoreactivity is mainly in a large molecular weight form corresponding to the atrial natriuretic peptide precursor. Although this finding would suggest that a 1:1 molar ratio of atrial natriuretic peptide to cardiodilatin should be obtained, the apparent non-equimolarity in our results is probably due to reduced cross reactivity of the antisera with the peptides in the uncleared precursor form and the uncertainty of the cross reactivity of antisera to human cardiodilatin with the rat form. The peptide sequence used differs by three amino acids from that of the rat. In the human atrium there is a 
Mean (SEM) concentrations (nmol/g wet tissue) of atrial natriuretic peptide $(A N P)$ and cardiodilatin as determined by radioimmunoassay

\begin{tabular}{|c|c|c|}
\hline Tissue & $A N P$ & Cardiodilatin \\
\hline $\begin{array}{l}\text { Right atrium } \\
\text { Extrapulmonary vein } \\
\text { Intrapulmonary vein } \\
\text { Peripheral lung }\end{array}$ & $\begin{array}{cl}218 \cdot 4 & (27) \\
62 \cdot 2 & (19 \cdot 4) \\
0 \cdot 145 & (0.06) \\
\text { ND } & \end{array}$ & $\begin{array}{ll}60.8 & (8.8) \\
6.8 & (2 \cdot 8) \\
0.045 & (0.01) \\
\text { ND } & \end{array}$ \\
\hline
\end{tabular}

ND-not detected.

molar ratio of nearly 1:1 between cardiodilatin and atrial natriuretic peptide immunoreactivities (L Meleagros, unpublished observation).

The present findings also confirm previous studies ${ }^{17-}$ 192931 showing that atrial myocardium extends along extrapulmonary and intrapulmonary veins of the rat. This seems to be a feature of rodents, for in other mammals, including man, the myocardium does not extend beyond the extrapulmonary veins. ${ }^{17}$ Possibly the extra-atrial myocardium helps to regulate pulmonary circulation, ${ }^{31}$ either by inhibiting blood passing $\stackrel{\infty}{\stackrel{9}{+}}$ from the atrium back along the pulmonary vein or by actually assisting in pumping blood into the left atrium. Even after cardiac pumping has stopped, in $\frac{\bar{s}}{\frac{6}{6}}$ cats and rabbits the thoracic pulmonary veins con- $\mathbb{\mathbb { }}$ tinue to pulsate independently ${ }^{32}$; this was confirmed by electrophysiological intracellular recording in guinea $\vec{\circ}$

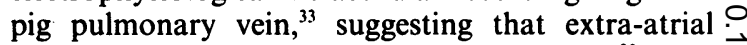
myocardium may have its own pacemaker. ${ }^{20}$ It is $\vec{\omega}$ logical that, if the venous myocardium serves such $\stackrel{\circ}{\circ}$ functions, it should extend further peripherally into $\overrightarrow{\vec{x}}$ the pulmonary vasculature of the smaller species since their pulmonary arteries and veins have a correspond- $\vec{\omega}$ ing small cross section, and therefore lung haemodynamic resistance is suggested to be much higher than in larger mammals such as man. ${ }^{31}$ The functional significance of atrial natriuretic peptide immunoreac- $\vec{c}$ tivity in pulmonary veins is uncertain, but the lungs have been shown to be an important site for the
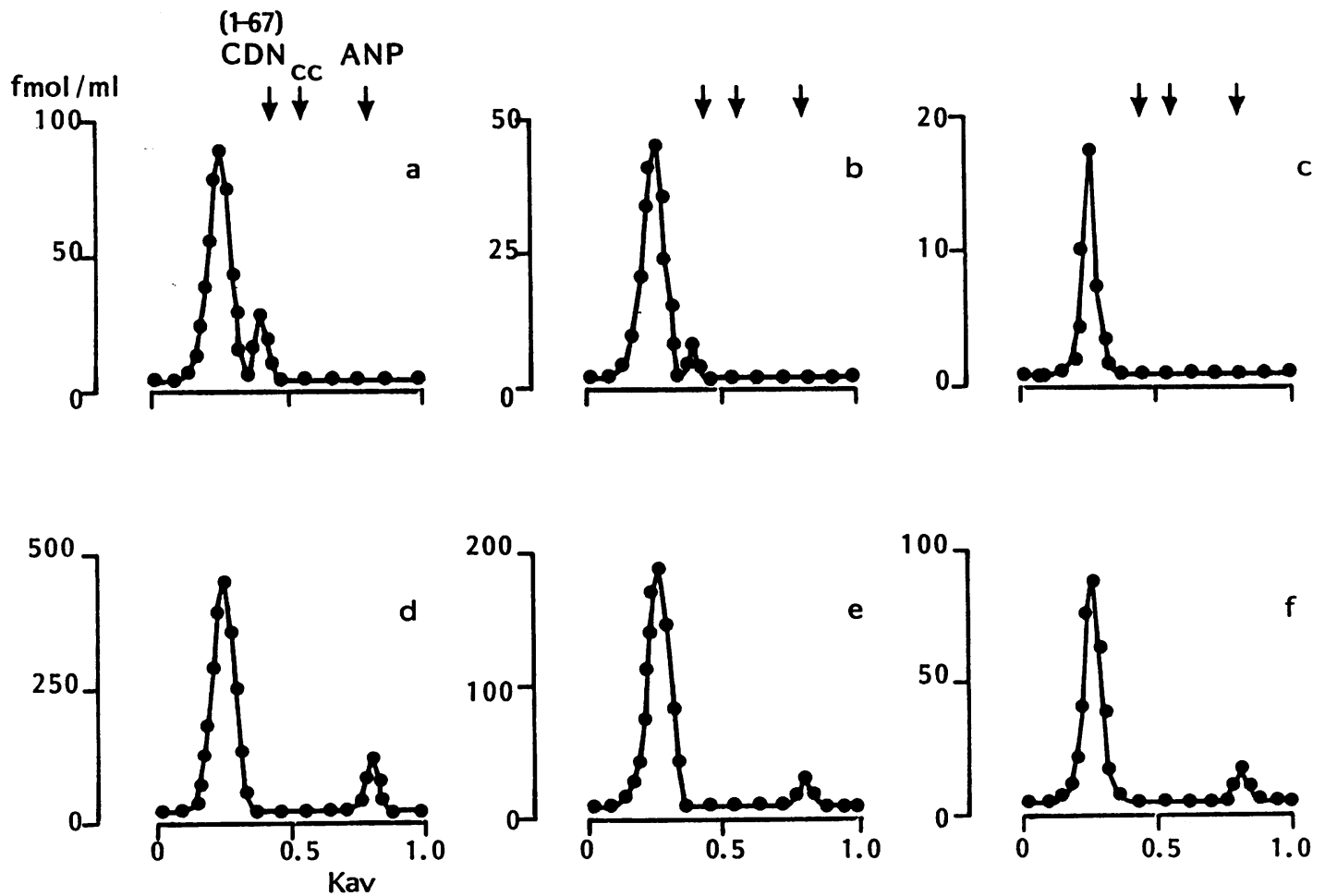

Fig 5 Gel permeation chromatography profiles of cardiodilatin $(a, b, c)$ and atrial natriuretic peptide $(d, e, f)$

immunoreactivities in extracts of atrial tissue $(a, d)$ and extrapulmonary $(b, e)$ and intrapulmonary $(c, f)$ veins. Most of the immunoreactivity for cardiodilatin and atrial natriuretic peptide is present in a single peak, which is detectable at the same elution position. A small peak that coelutes with the synthetic $\alpha$ rat atrial natriuretic peptide is present in the extracts of atrial tissue $(d)$ and extrapulmonary $(e)$ and intrapulmonary $(f)$ veins. Similarly, a small cardiodilatin peak is present, eluted after the major peak common to cardiodilatin and atrial natriuretic peptide, in extracts of atrial tissues (a) and extrapulmonary veins $(c)$. This cardiodilatin peak is eluted earlier than the synthetic cardiodilatin asn'-arg ${ }^{67}$ (CDN 1-67) and at a point where no atrial natriuretic peptide immunoreactivity is found. 
metabolism of the peptide. When labelled with iodine125 and injected into anaesthetised rats most of the peptide is taken up by the lungs, ${ }^{34}$ and this uptake was found to be saturable in an in vitro rabbit lung preparation. ${ }^{35}$ In both cases the binding of radiolabelled ligand was prevented by pretreatment with excess unlabelled peptide, and it has been suggested that the removal of atrial natriuretic peptide by the lung may be an additional means of controlling the circulating levels of the peptide. ${ }^{35}$

The mechanism causing release of atrial natriuretic peptide from pulmonary veins is uncertain. The peptide is released from the heart by atrial stretch ${ }^{36}$ and volume loading, ${ }^{37}{ }^{38}$ and may also be released from dog pulmonary vein by stretching. ${ }^{39}$ Interestingly, in this study atrial natriuretic peptide and cardiodilatin immunoreactivities were less in the pulmonary veins of rats that were fixed by perfusion. The pressure of perfusion fluid could cause stretch of the vessels and thus release of the peptides. Release of atrial natriuretic peptide from atria of perfused isolated rat and rabbit hearts has been found when the perfusion fluid was made hypoxic, ${ }^{40}$ and it has been shown in vivo in hypoxic rats. ${ }^{38}$ Atrial natriuretic peptide also causes constriction of coronary arteries ${ }^{41}$ and may act to reduce the pulmonary vasoconstriction that occurs in hypoxia. ${ }^{42}$ Thus atrial natriuretic peptide release from intrapulmonary veins may have a local paracrine effect in addition to contributing to the circulating concentrations of the peptide.

Part of this work was carried out with the generous support of the Council for Tobacco Research (USA), the British Heart Foundation, and Amersham International PLC.

\section{References}

1 Forssmann WG, Hock D, Lottspeich F, et al. The right auricle of the heart is an endocrine organ. Anat Embryol 1983;168:307-13.

2 Kangawa K, Matsuo $\mathrm{H}$. Purification and complete amino acid sequence of $\alpha$-human atrial natriuretic polypeptide ( $\alpha$-hANP). Biochem Biophys Res Commun 1984;118:131-9.

3 Oikawa S, Imai M, Inuzuka C, Tawaragi Y, Nakazato H, Matsuo H. Structure of dog and rabbit precursors of atrial natriuretic polypeptides deduced from nucleotide sequence of cloned cDNA. Biochem Biophys Res Commun 1985;132:892-9.

4 Ong H, McNicoll N, Lazure C, et al. Purification and sequence determination of bovine atrial natriuretic factor. Life Sci 1986;38:1309-15.

5 Seidah NG, Lazure C, Chrétien M, et al. Amino acid sequence of homologous rat atrial peptides: natriuretic activity of native and synthetic forms. Proc Natl Acad Sci USA 1984;81:2640-4.

6 Cantin M, Gutkowska J, Thibault G, et al. Immunocyto- chemical localization of atrial natriuretic factor in the heart and salivary glands. Histochemistry 1984;80: 113-27.

7 Anderson JV, Cristofides ND, Vinas P, et al. Radioimmunoassay of alpha rat atrial natriuretic peptide. Neuropeptides 1986;7:159-73.

8 Solcia E, Capella C, Buffa R, Usellini L, Frigerio B, Fontana P. Endocrine cells of the gastrointestinal tract and related tumors. In: Ioachim HL, ed. Pathobiology annual. Vol 9. New York: Raven Press, 1979:163-204.

9 Gardner DG, Deschepper CF, Ganong WF, et al. Extraatrial expression of the gene for atrial natriuretic factor. Proc Natl Acad Sci USA 1986;83:6697-701.

10 McKenzie JC, Tanaka I, Misono KS, Inagami T. Immunocytochemical localisation of atrial natriuretic factor in the kidney, adrenal medulla, pituitary and atrium of rat. J Histochem Cytochem 1985;33:828-32.

11 Stone R, Glembotski CC. Immunoactive atrial natriuretic peptide in the rat eye: molecular forms in anterior uvea and retina. Biochem Biophys Res Commun 1986;134:1022-8.

12 Zamir N, Skofitsch G, Eskay RL, Jacobowitz DM. Distribution of immunoreactive atrial natriuretic peptides in the central nervous system of the rat. Brain Res 1986;365:105-11.

13 Sakamoto M, Nakao K, Morii N, et al. The lung as a possible target organ for atrial natriuretic polypeptide secreted from the heart. Biochem Biophys Res Commun 1986;135:515-20.

14 Hamid Q, Wharton J, Terenghi G, et al. Localization of atrial natriuretic peptide $\mathrm{mRNA}$ and immunoreactivity in the rat heart and human atrial appendage. Proc Natl Acad Sci USA (in press).

15 Nemer M, Lavigne J-P, Drouin J, Thibault G, Gannon M, Antakly T. Expression of atrial natriuretic factor gene in heart ventricular tissue. Peptides 1986;7: 1147-52.

16 Lattion A-L, Michel J-B, Arnauld E, Corvol P, Soubrier F. Myocardial recruitment during ANF mRNA increase with volume overload in the rat. Am J Physiol 1986;251:H890-6.

17 Nathan H, Gloobe H. Myocardial atrio-venous junctions and extensions (sleeves) over the pulmonary and caval vein. Anatomical observations in various mammals. Thorax 1970;25:317-24.

18 Stieda L. Über quergestreifte Muskelfasern in der Wand der Lungenvenen. Arch Morph Anat 1877;14:243-8.

19 Favaro G. Il miocardio polmonare. Contributi all' istologia umana e comparata dei vasi polmonari. Int Monatschr Anat Physiol 1910;27:375-407.

20 Masani F. Node-like cells in the myocardial layer of the pulmonary veins of rats: an ultrastructural study. $J$ Anat 1986; 145:133-42.

21 Huang W-M, Gibson SJ, Facer P, Gu J, Polak JM. Improved section adhesion for immunocytochemistry using high molecular weight polymers of L-lysine as a slide coating. Histochemistry 1983;77:289-302.

22 Springall DR, Hacker GW, Grimelius L, Polak JM. The potential of the immunogold-silver staining method for paraffin sections. Histochemistry 1984;81:603-8.

23 Bancroft JD, Stevens A. Histopathological stains and their diagnostic uses. Edinburgh: Churchill Livingstone, 1975:3-6. 
24 Sternberger LA. The unlabelled antibody peroxidaseanti-peroxidase (PAP) method. In: Sternberger LA, ed. Immunocytochemistry. 2nd ed. New York: John Wiley and Sons, 1979:104-69.

25 Kangawa $\mathrm{K}$, Tawaragi Y, Oikawa S, et al. Identification of rat atrial natriuretic polypeptide and characterization of the cDNA encoding its precursor. Nature 1984;312:152-5.

26 Minth CD, Bloom SR, Polak JM, Dixon JE. Cloning, characterisation, and DNA sequence of a human cDNA encoding neuropeptide tyrosine. Proc Natl Acad Sci USA 1984;81:4577-81.

27 Hoefler H, Childers H, Montminy MR, Lechan RM, Goodman RH, Wolfe HJ. In situ hybridization methods for the detection of somatostatin mRNA in tissue sections using antisense RNA probes. Histochem $J$ 1986;18:597-604.

28 Meleagros L, Ghatei MA, Anderson JV, et al. The presence and molecular forms of cardiodilatin immunoreactivity in the human and rat right atrium. Clin Chim Acta (in press).

29 Klavins JK. Demonstration of striated muscle in the pulmonary veins of the rat. J Anat Lond 1963;97: 239-41.

30 Jamieson JD, Palade GE. Specific granules in atrial muscle cells. J Cell Biol 1964;23:151-72.

31 Karrer $\mathbf{H}$. The striated musculature of blood vessels. 1. General cell morphology. J Biophys Biochem Cytol 1959;6:383-92.

32 Brunton TS, Fayrer J. Note on independent pulsation of the pulmonary veins and vena cava. Proc $R$ Soc Lond 1874;B25:174-6.

33 Cheung DW. Electrical activity of the pulmonary vein and its interaction with the right atrium of the guinea $\overrightarrow{\vec{F}}$ pig. J Physiol 1980;314:445-56.

34 Sardella GL, Yen S, Ou LC. Further evidence for an important role of the atrial natriuretic factor (ANF) in 흠 pulmonary circulation [abstract]. Fed Proc 1987; $\frac{\bar{\Phi}}{\bar{Q}}$ 46:518.

35 Turrin M, Gillis CN. Removal of atrial natriuretic peptide by perfused rabbit lungs in situ. Biochem ${ }^{\text {s }}$ Biophys Res Commun 1986;140:868-73.

36 Lang RE, Thölken H, Ganten D, Luft FC, Ruskoaho H, Unger Th. Atrial natriuretic factor-a circulating $\vec{\omega}$ hormone stimulated by volume loading. Nature 1985;314:264-6.

37 Atlas SA, Kleinert HD, Camargo MJ, et al. Purification, sequencing and synthesis of natriuretic and vasoactive $\omega$ rat atrial peptide. Nature 1984;309:717-9.

38 McKenzie JC, Tanaka I, Inagami T, Misono KS, Klein $\stackrel{\vec{A}}{\circ}$ RM. Alterations in atrial and plasma atrial natriuretic옥 factor (ANF) content during development of hypoxia- induced pulmonary hypertension in the rat. Proc Soc Exp Biol Med 1986;181:459-63.

39 Sutton PMI, Abed JSM, Nashat FS. Retrograde infusion of blood into a pulmonary vein promotes natriuresis in anaesthetised dogs. $Q J$ Exp Physiol 1986;71:609-14. $\vec{\bullet}$

40 Baertschi AJ, Hausmaninger C, Walsh RS, Mentzer RM ${ }_{\infty}^{\infty}$ Jr, Wyatt DA, Pence RA. Hypoxia-induced release of atrial natriuretic and vasoactive rat atrial peptide. Biochem Biophys Res Commun 1986;140:427-33.

41 Ackerman U. Cardiovascular effects of atrial natriuretic $\bar{\partial}$ extract in the whole animal. Fed Proc 1986;45:2111-4.

42 Ou LC, Sardella GL, Hill NS. Pulmonary and systemic $\stackrel{\square}{\Phi}$ hemodynamic and diuretic effects of atrial natriuretic $\overrightarrow{ }$ factor (ANF) in chronically instrumented rats [abs-음 tract]. Fed Proc 1987;46:518. 